Jukka Anteroinen:

National Defense University, Helsinki, Finland

\title{
ENHANCEMENT OF NATIONAL COLLABORATION BETWEEN DEFENCE ESTABLISHMENT AND INDUSTRY BY SYSTEMS APPROACH
}

\begin{abstract}
The objective of this paper is to discuss current challenges of specific collaboration mechanisms between the defence establishment and national defence industry and to present a holistic, conceptual co-operation model of systems approach, based on discussion to enhance that cooperation. This survey focuses mainly on problems that are related to defence technology and industrial strategies. A special emphasis is placed on collaboration activities and mechanisms between the above mentioned partners; technology programmes, industrial participation, defence centres of excellence and immaterial property rights to reveal collaboration dilemmas from various aspects. The conceptual model of systems approach pursues to manage cooperation activities and mechanisms comprehensively and so fulfil expectations placed for the collaboration both by the defence establishment and the industry. Applicability and value of the model is verified by risk analysis.

The paper has a Finnish focus and it delineates the challenges identified with Finnish examples. However, the model that it represents is of universal application, especially for countries that do not have a comprehensive defence industry but import the major part of their materiel from abroad.
\end{abstract}

\section{Keywords:}

systems approach; national defence collaboration, defence establishment; defence industry; Defence Centre of Excellence, industrial participation, defence technology strategy

\section{Introduction}

There is a wide acceptance in the academic literature that European countries should consolidate their national defence technological and industrial efforts to common European defence technological and industrial base (EDTIB) in order to attain_better military capabilities and industrial competitiveness more costeffectively ${ }^{(1),(2),(3)}$. In reality, the EDTIB initiative was created and is currently lead by the European Defence Agency (EDA) $)^{(4)}$. National defence technological and 
industrial protectionism is, for obvious reasons, seen as hindrance for implementation of EDTIB. However, it is still justifiable to claim that domestic, defence-related research and development $(\mathrm{R} \& \mathrm{D})$ capabilities are needed to develop and maintain the knowledge base that supports industrial-military selfsufficiency to some degree during peacetime and that enhances the security of supply in wartime ${ }^{(5)}$ Equally, it is easy to understand that usually national business success and industrial competitiveness lay the foundation for international collaboration. Hence, there is also a need and rationale for national collaboration between the defence establishment (defined as Ministry of Defence (MoD) as a whole consisting both of political component and the military component of the MoD) and industry to support the creation and sustainment of military capabilities and to promote the competitiveness of national defence industry. This is also true for smaller countries, such as Finland, which do not possess a full scale technological and industrial base.

Contemporary literature concentrates mainly on individual collaboration mechanisms and its perspective is usually industry focused or economic-driven. Capability aspect is not dealt substantially. In addition, there seems to be a tendency to view issues on multinational, e.g. European Union (EU) level, instead of viewing them with a national focus in mind. Similarly, issues are usually viewed from the perspective of large defence industrial countries ${ }^{(2)}$ rather than smaller countries.

In contrast, this paper views things from the perspective of small and medium-sized countries (SMC) ${ }^{1}$ perspective and uses Finland as an example of SMC. Likewise, this paper approaches the collaboration issue from the national perspective. It is still essential that national preconditions, e.g. competitiveness to enable international collaboration, exist and that national collaboration is managed in a cost-effective manner. Moreover, unlike many other studies that deal in detail with individual mechanisms and instruments, this paper proposes a conceptual and multi-faceted model to enhance cost-effectiveness.

Finland is one of the largest military material importers in Europe ${ }^{(6)}$. In 2006, the fraction of the domestic defence procurement, which included spare parts and maintenance, was $48 \%$ of the total procurement spending. In systems and material procurement, however, the Finnish defence industry supplied $20 \%$ of the total value of the materiel ${ }^{(7)}$. These figures indicate that Finland does not have a comprehensive defence industry, but rather expertise in niche areas, which it 
continues to strengthen by its defence industrial and technology strategies. These niche areas are mainly scattered in the small and middle-sized enterprises (SME) and do not form, in many cases, large competence areas. Consequently, it would not be realistic for Finland to try to develop large state-of-art military systems relying solely on domestic industry. However, it is vitally important that the systems, which provide core military capabilities, are operable and maintainable at all times in Finland, in the times of crisis as well as through the systems' life cycle $^{(6)}$. Reaching this aim requires close collaboration between the national defence establishment and industry.

In fact, there are currently several mechanisms in place to manage and foster this collaboration. These mechanisms include defence technology and industrial strategies as well as organisational instruments such as centres of excellence.

Nevertheless, these mechanisms are currently not managed comprehensively, as a whole, but rather they are seen and handled as stand-alone instruments as will be explained later in the paper. Relations of the mechanisms with potential interacting systems have not been clearly defined and are vague at best. This fragmented approach of collaboration does not provide the best value for money either for public, military or industrial purposes. In addition, the approach poses risks both for capability and competitiveness creation and sustainment.

The objective of this paper is to discuss current challenges of the above mentioned collaboration mechanisms and instruments between the defence establishment and national defence industry and to present a holistic, conceptual co-operation model of systems approach, based on discussion to enhance that cooperation.

\section{Systems Approach to enhance collaboration}

It is believed that systems approach helps to see and understand the collaboration between the defence establishment and national defence industry more comprehensively, which in turn supports enhancing the cost-effectiveness of this cooperation. In other words, the idea of national enhancement of this collaboration with the help of systems approach is to be able to capture all collaboration elements and mechanisms into a comprehensive model to produce desired outcomes for all stakeholders.

The meaning and application of the systems approach was defined in the late 1960's. Churchman ${ }^{(8)}$, who described the characteristics of the systems approach to problem solving ${ }^{(9)}$, states that the systems approach is simply a way of 
thinking about the systems in question and their components. There is a common understanding that the systems approach means that systems are considered holistically ${ }^{(10),(11),(12)}$ and explored top-down ${ }^{(8),(13),(14)}$. Furthermore, it is accepted that viewing and studying systems as parts of larger systems is the fundamental characteristics of the systems approach ${ }^{(14),(15)}$. Moreover, the systems approach is a problem solving concept, an attitude or an ability to look at wholes, different levels and interrelationships rather than a formal method ${ }^{(11)}$. The status of systems as an approach rather than a body of knowledge means that this type of thinking can be applied very widely and it is adoptable to any area of human inquiry. This "meta" nature of systems, enables the structuring of systems research into three types of systems; concepts (framework of ideas), methodologies and real-world entities. Systems framework of ideas is applied, in accordance with some systems methodology, in many areas of application, i.e. the real world systems ${ }^{(16)}$. Consequently, in this paper, the systems approach is applied as follows:

- the framework of ideas is enhancement of national defence industrial competitiveness and military capability. Competitiveness is defined as ability of a firm or a nation to offer products and services that meet the quality standards of the local and world markets at prices that are competitive and provide adequate returns on the resources employed or consumed in producing them ${ }^{(17)}$. Competitiveness is primarily related to the industry. The definition includes an economic aspect as well (adequate returns on the resources), which is relevant factor also for military forces and the people. Military capability is the ability to achieve a specified wartime objective ${ }^{(18)}$ and mainly linked to the military establishment. The enhancement of the competitiveness and the capability is understood to represent the outcomes (ends) for the collaboration. This framework of idea is compliant with the European Defence Agency's (EDA) Strategy for the European Defence Technological and Industrial Base (EDTIB), although EDA's strategy focuses on the European industrial base rather than on purely national efforts ${ }^{(4)}$. The EDTIB strategy, as well as the model proposed in this paper, pursue an industrial base that is capability driven, competent, and competitive, and brings real economic value. By doing this it helps to maintain public support for national defence. The difference, however, is that the EDTIB strategy outlines just aims and strategic goals, while this paper proposes a conceptual solution to realise capability, competitiveness and competency aspirations. In any case, the strategy of EDTIB includes the required perspectives, i.e. views for this study, which are capability, 
competitiveness, and economic views. Furthermore, the EDTIB's competency perspective has been included as a management view in this paper. These views will be used to structure discussions about the current risks of the collaboration between the defence establishment and the defence industry. The structuring, in turn, helps to perceive interdependencies between the collaboration mechanisms. The views are called "collaboration views" later in the paper.

- the systems methodology consists of risk analysis and systems engineering techniques to reveal the weaknesses of the current situation and to increase the understanding of interdependencies and relations of various collaboration mechanisms. Likewise, the systems engineering techniques are used to describe the holistic model.

- the area of application is the collaboration mechanisms between the defence establishment and national defence industry. The mechanisms include

- technology programmes that are part of the defence technology strategy

- $\quad$ industrial participation (IP), which is an element of the defence industrial strategy

- defence centres of excellence (DCoE) representing the organisational collaboration instrument and

- immaterial property rights (IPR) as an incentive to promote the collaboration

The collaboration mechanisms are seen as "means", i.e. instruments to achieve the aforementioned aims. The application of systems approach in this paper is visualised in Figure 1.

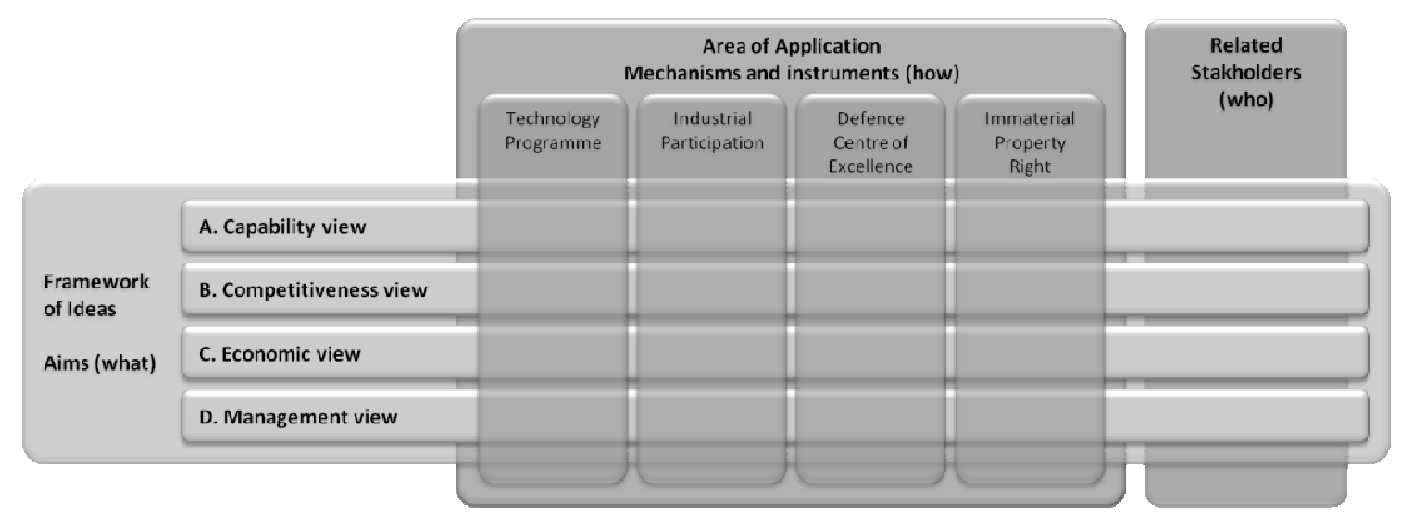

Figure 1. Application of systems approach in the paper 
The applicability of widely known strategic planning and management model, Balanced Score Card, was also considered for this work, for it is a multifaceted method including financial, customer, processes and learning and growth aspects. However, the model was not found suitable for this conceptual study because the Balanced Score Card is meant to be applied comprehensively to define vision and strategy and translate them into action, including defining necessary metrics. In this work, the need was just to find a comprehensive set of views to be able to see and enhance the collaboration between the defence establishment and the defence industry systemically.

\section{Related study}

This paper supplements current literature by looking collaboration from the national perspective. The national defence collaboration lays a foundation for the international collaboration that is the focus area in many of the related papers.

Hartley ${ }^{(1)}$ discusses industrial collaboration issues within the EU. Hartley's paper deals mainly with improving the competitiveness and economics in Europe with the help of common European defence industrial base. This is done especially to compete with the U.S. defence industry. His paper recommends international collaboration instead of purely national industrial independence. However the paper admits that the defence market does not always follow the economic theory due to non-price factors, such as security of supply. Additionally, the paper identifies that nations may aim to protect their domestic defence industrial base for military-strategic reasons, such as security of supply, operational sovereignty and/or for economic reasons in terms of jobs and technology, although the EU Code of Conduct on Defence Procurement targets to decrease this national emphasis.

Struys ${ }^{(2)}$ writes about the future of the defence firms in small countries and sees that international collaboration is the key for their survival instead of national protectionism. However, his solution for the survival dilemma is the defence convergence in Europe, i.e. a common European industrial and technological base. Struys also states that the defence industry in small countries should specialise to have a relevant role in the supply chain. However, Struys does not discuss in detail how this specialisation or pole-of-excellence position can be achieved nationally.

$\mathrm{James}^{(19)}$ too studies the defence industry and co-operation in the European-level framework. Similarly to Struys and Hartley and Braddon, James suggests a strengthened and common European industrial base ${ }^{(3)}$. Additionally, he 
proposes building "defence industrial towers of excellence" to Europe to be able to co-operate with the U.S as an equal partner. His proposal is analogous to this paper's rationale that one has to be competent enough to be able to co-operate successfully with others. Nonetheless, James has the European-level scope in his paper. Furthermore, James's towers of excellence are more conceptual in nature, while the centres of excellence discussed in this paper are meant to be legal and most likely physical entities.

Wylie et al. ${ }^{(5)}$ examine rationale for government funded defence $R \& D$ using Australia as target case. Their paper studies whether a small nation should invest own funds to gain strategic sovereignty, i.e. necessary military capabilities indigenously or rely on alliances partly or wholly. In this paper, the focus is not to question the need for government funded R\&D, but on how to take advantage of R\&D investment to support local industry and military capabilities. However, Wylie et al. list in their study key features of a small country defence innovation system, which include for instance incentives, institutions and knowledge development. Those features are also elements of the holistic collaboration model proposed in this paper.

Bellais and Guichard ${ }^{(20)}$ study defence R\&D and innovation and especially technology spin-off issues including immaterial property rights (IPR).

Nevertheless, their focus is on countries with a substantial defence industrial and technology base, e.g. France, where R\&D is often carried out by the defence laboratories. In this paper, the focus is on a smaller country, such as Finland, where the defence industry carries out the major part of $R \& D$ funded by the defence establishment. Therefore it is more likely that there will be more spin-on (civil technology applied to the defence sector) than spin-off (defence technology used in the civil sector) cases in a country such as Finland. It should be noted that Kelly et al. ${ }^{(21)}$ argue against positive spin-off effects. However, they view the issue more from the general military spending perspective than the R\&D spin-off perspective. Moreover, in this paper, the rationale is to view $R \& D$ in relation to other defence industrial mechanisms rather than discussing the effectiveness of $R \& D$ alone or the spin-off effects of military spending in general.

McGuire ${ }^{(22)}$ discusses methods to decrease the effects of interruption in supply, i.e. ways to enhance security of supply. His paper is too specific for the purpose of this paper, for it argues whether we should use stockpiling, provision of domestic production or a specific mix of those to secure our national supply. This paper accepts that all of these means are needed. In addition, the focus of this paper is the industrial capability (provision of domestic production). 


\section{Description and challenges of current collaboration mechanisms}

Collaboration mechanisms between the defence establishment and the defence industry include defence technology and industrial strategies as well as organisational instruments such as centres of excellence. Defence technology strategy attempts to create and maintain sufficient technological base at home, while defence industrial strategy pursues to maintain required industrial competencies onshore. Centre of excellence scheme is one way to implement the defence industrial and technology strategies and related activities. These collaboration mechanisms are briefly introduced in the next chapters. In addition, their current challenges are discussed.

\subsection{Defence Technology strategy and its related activities}

Generally, a technology strategy is the part of the overall business strategy of an organisation that enables the organisation to be as competitive as possible ${ }^{(23)}$. This idea is applicable to commercial firms as well as armed establishments, although the measures of competitiveness vary in different kinds of organisations. For commercial firms, this measure is usually connected to profit. In military organisations, competitive advantage equals enhanced military capability. Hartley underlines the essence of $R \& D$ stating that defence $R \& D$ spending determines the quality of military equipment.

One instrument to implement the defence technology strategy is the defence technology programmes. They aim at demonstrating the feasibility of defined technologies in the military context in order to increase knowledge and decrease risks in the later development phases of products and services. From the defence establishment's perspective the interest is to increase the knowledge and understanding of applied technologies. Increased knowledge of personnel is needed to be able to act as an intelligent customer in oncoming materiel procurement projects. From the industry's perspective, the objective is, above all, to create or strengthen the knowledge of demonstrated technologies to create basis for new products and services. In Finland, technology programmes' technological maturity level is $4-6$ on a scale of $1-9$. On this scale, 1 equals basic research and 9 indicates equipment ready for field use.

Thus, the deliverables of the programmes are not final products or services, but rather evidence of feasibility and maturity of the studied technologies 
to be further developed to products. Hence, these technology programmes do not create immediate business for the industry but are rather catalysts for longer term business strategies. Similarly, the efficiency, i.e. add-on value in final products, of these kinds of research and development programmes is challenging to assess. This problem is also noted by Hartley ${ }^{(24)}$.

Additionally, technology programmes in Finland are not automatically followed by prototype projects or other development steps due to lack of required funding and industrial base.

Consequently, the achieved knowledge is not easily maintained by the industry unless it decides to invest its own money to develop technology demonstrators into new products. Industry's willingness to infuse capital into product development naturally requires some level of certainty for the future business potential of these products. Within the Finnish context, where the full development path of products is seldom financed, the industry should be incentivised by other means to maintain and further develop the knowledge base into a long-term competence and competitiveness.

\subsection{Defence industrial strategy related activities}

In military procurements from abroad, the purchasing country commonly requires industrial participation (the term 'offset' is also used) from the seller company. Industrial participation (IP) is one key mechanism to create and maintain the industrial base in countries with non-comprehensive defence industry ${ }^{(6)}$. Ultimately, a common European DTIB should be able to create market conditions where there is no need for offsets. Nevertheless, European countries have accepted that in the current situation there is still need for offsets. The participating member states of the EDA have even agreed a code of conduct on offsets ${ }^{(25)}$ in order to evolve towards more transparent use of industrial participation in Europe.

IP is usually focused on strategic competence areas that are specified and concrete products or service areas of the defence industry, wherein knowledge and skill-set development and maintenance are to be retained by the host nation to contribute to the security of supply. ${ }^{(26)}$ These areas are based on the defence establishment's needs and are derived from its long-term plans. In Finland the aim of IP is to secure the maintenance and integration knowledge for Finland and to enable technology insertion into Finland ${ }^{(27)}$.

IP is usually directed towards maintaining and developing the defence industry of the purchasing country but it can also be used to foster other industrial 
and economic policy aims. In Finland, industrial participation is a precondition set by the Finnish Parliament for large foreign military procurements. IP is required as a rule when the value of the procurement rises above EUR 10 million. ${ }^{(28)}$ Acquisition of foreign defence systems would be difficult to advocate without an IP mechanism to adjust the balance in trade. Alternatively, all the jobs, investment and technology would remain with the foreign supplier. The cost of delivering offset to buyers varies between $3 \%$ to $10 \%$ on the total contract price ${ }^{(29)}$. This fraction of the contract price could be interpreted as a direct loss of primary capability from the military perspective, i.e. three to ten tanks of total 100 hundred tanks lost due to IP obligations. Correspondingly, it is necessary to balance this loss for instance by creating a maintenance capability onshore to increase security of supply and to secure that the investments remain in home country during the operations phase of the systems' life cycle.

The Finnish Defence Industrial Strategy's statement that IP shall be directed primarily to strategic competence areas is a very significant declaration and gives huge leverage for the industry ${ }^{(6)}$. There is a potential for a solid business base in defined competence areas. However, this incentive created by the IP guidance should not be taken as a cornucopia for the industry but as a long-term commitment of the defence establishment to promote national industry, if necessary industrial pre-conditions for support exist to gain win-win situation. These prerequisites are naturally appropriate competitiveness both in quality of services and products and in their prices.

In Finland, the technology and industrial strategies are parts of materiel political strategy of MOD ${ }^{(27)}$, but the only identified connection between them is the strategic competence areas. Collaborative technology and industrial activities should be directed to those areas in accordance with the strategies. However, how these mechanisms contribute to each other has not been defined.

\subsection{Defence Centres of excellence (DCoE)}

The specialisation and creation of poles of excellence is seen as a key survival means for the defence industry in small countries ${ }^{(2)}$. Common EDTIB also calls for the development of European centres of excellence to facilitate competitiveness creation ${ }^{(25)}$. There are also national initiatives to enhance competitiveness by implementing centres of excellence scheme. In Finland, The Defence White paper in $2004^{(30)}$ demanded that the vital competence areas, which were defined in Chapter 4.2, should be supported by the Defence Centres of Excellence (DCoE). 
The supplementary report of the Defence Technology Strategy in $2005^{(31)}$ repeated the need for establishing technology strategy related DCoEs, in order to provide an optimal environment to develop the critical technologies into appropriate competences, products and services. Likewise, the Finnish Defence Industrial Strategy in year $2007^{(6)}$ directed that DCoEs should to be built in the area of systems integration. The industrial strategy also imposed that the DCoEs should be implemented based on the needs of the Finnish Defence Forces and in co-operation with the defence industry and academia. Consequently, there are both technology and industrial driven demands for the establishment of DCoEs.

However, the described documents have not laid any other tangible guidance for the DCoE establishment. Therefore, it is not a surprising to see that the definition and establishment of the centres of excellence are still in progress in Finland.

\subsection{Immaterial property rights (IPR)}

One effective way of encouraging industry to engage with the collaboration is immaterial property rights (IPR) ${ }^{(20)}$. In Finland, the current procurement guidance states that the defence establishment would, in general, retain all IPRs in development projects, which are ordered and paid for by the defence establishment alone ${ }^{(32)}$. This rule effectively impedes the further utilisation of the innovation by the developer, i.e. industry. The Finnish Defence Industrial Strategy in 2007 identifies that IPRs should be aligned so that they are owned by the industry and utilisable also in international business. However, the amendment of this IPR policy has not yet been implemented. Bellais and Guichard discuss in detail the legal framework, which would be needed to hand-over the IPRs properly to the industry.

It should be noted that this incentive should also include obligations to the defence industry. It should carry part of the development risk by investing its funds in technology development. This would be real burden sharing. However, the defence establishment should assure that full rights to use and modify the developed technologies and products are retained by the defence establishment in all situations. Equally, the establishment should receive royalties from the mutually developed products, which are sold abroad.

\subsection{Risks of current implementation approach}

The major risks associated with the above described, non-cohesive approach are listed in Table 1. These risks have not been assessed as a product of 
impact and probability because there are no published impact and probability data available. On the contrary, the risks are just identified and listed without severity considerations. In addition, the risks have been categorised in accordance with the collaboration views of the paper; capability, competitiveness, economic and management issues in order to structure and study the problem areas systematically.

From the capability perspective, the major risk is that the desired security of supply is not achieved due to either technology programmes that fail to create necessary industrial competitiveness or the fact that industrial participation is not focused on strategic areas. The main competitiveness risk is that the industry is simply not competent to deliver products for the local defence establishment or for their international customers due to a mismatch between the technology programmes working areas and the customer's product needs. Moreover, without centres of excellence, local unconsolidated industry can not create critical mass to deliver the required industrial work. On the economic side, the key risk is that the invested public funds are not returned back to the country of origin to contribute to the creation or sustainment of its defence capabilities. This happens if the defence industry is not capable of IP work, but the country has to rely on indirect IP (e.g. IP work ordered from the civilian sector). From the management perspective, multiple business counterparts instead one point of contact, i.e. a centre of excellence, pose a risk of decreased management efficiency between the industry and defence establishment. This may result increased costs, time delays and even loss of contracts. 
Risks in current, fragmented collaboration schemes

A. Capability issues

A1. Security of supply not achicved

A2. No domestic insertion to improve capabilities

B. Competitiveness issues

B1. Critical mass of competence not achieved to deliver large IP work

B2. Industry not competent to deliver products or IP work

B3. Technology programme alone does not incentivise industry to invest in competence areas

C. Economic issues

C1. Invested public funds are not returned to contribute defence capabilities

C2. Invested funds for technology programmes decrease funds available for materiel procurement

C3. Through life costs of materiel stay not fully onshore due to non-involvement of domestic industry in maintenance

C4. IPR incentives do not yield tangible profit to defence forces

\section{Management issues}

D1. Management of technology programmes and IP less efficient because of multiple counterparts

D2. DCoEs, technology programmes and IP increase workload, but products no concrete results

Table 1. Risks of current collaboration between the defence forces and national industry

\section{Interdependency of various collaboration mechanisms}

In reality, different mechanisms and issues have strong interdependencies with each other. Technology programmes enable increasing knowledge and preparedness for new innovations, which in turn, builds up competitiveness. In addition, technology programmes assist the defence establishment to be not just a demanding but also an intelligent customer of military equipment. Industrial participation (IP) provides a business base for domestic industry but increases industry's competitiveness and supports creation of international partnerships as well. IP supports the creation of security of supply, which is one element of the overall defence capability. Likewise, the ability to acquire modern materiel, which is not based on immature technology, supports the capability creation, decreases risks and adds value for money.

Figure 2 depicts the dependencies and interactions of the aforementioned mechanisms and issues in detail as an influence diagram. The drawn interactions 
and the dependencies both in Figure 2 and Table 2 are author's own contributions based on the descriptions of the existing mechanisms (Chapter 4) and related references. The graph also shows how the industrial participation, technology programmes, centres of excellence and immaterial property rights link together through various issues and factors. The issues have been grouped into capability, competitiveness, economic and management clusters as they were in Table 1 to clarify dependencies between the collaboration views and mechanisms and stakeholder interests.

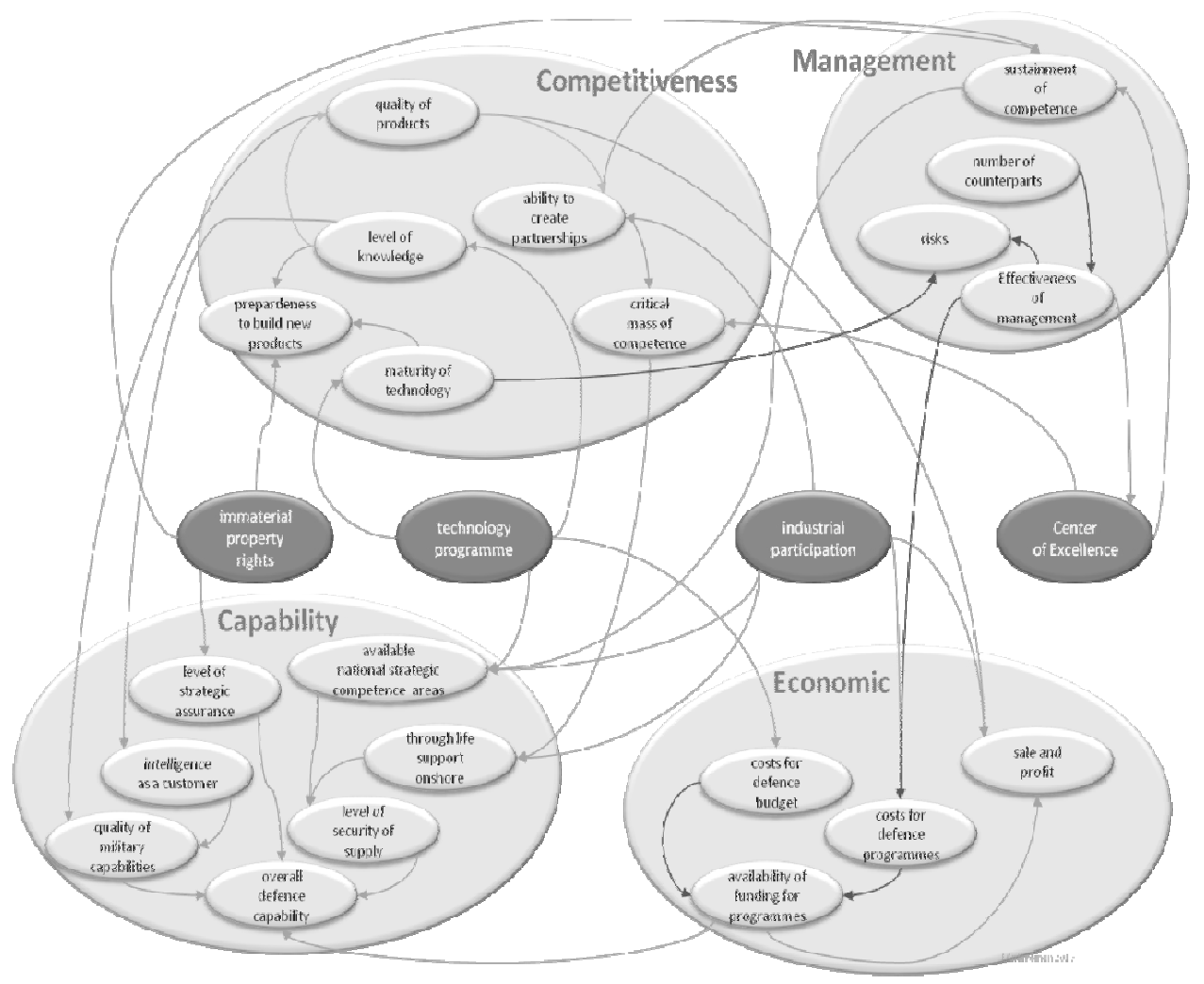

Figure 2. Influence diagram about the collaboration views and mechanisms between defence establishment and industry. Light grey arrow lines represent positive and dark grey arrow lines negative influences

The influence diagram is an efficient technique to reveal and visualise the interdependencies between the collaboration views and mechanisms. Nonetheless, it is challenging to perceive the key information of the diagram at a glance. Hence, a summary matrix about the above mentioned interdependencies and the related reasons and interests has been created on the basis of the influence diagram. The 
matrix is shown as in Table 2. It illustrates how the collaboration views; capability, competitiveness, economic and management relate in practice with the existing collaboration mechanisms; technology programmes, industrial participation, centres of excellence and immaterial property rights. Moreover, the main stakeholders of each collaboration view have been included in the table. Each vertical column of the table shows the main purpose of a specific mechanism from all collaboration perspectives. In other words, a column rationalises the existence of a mechanism from defence establishment, defence industry and public point of views. For instance, the economic purpose of the centre of excellence is to decrease costs, while creating a critical mass of competence is its idea from the competitiveness perspective. Each horizontal row of the table presents the interests of the main stakeholders related to that specific view in the different collaboration mechanisms.

As an example, the main interest of the defence industry from the competitiveness perspective during the industrial participation is to be able to network with international partners. An intersection of a view and a mechanism depicts a rationale for the mechanism from the perspective of that specific view.

\begin{tabular}{|c|c|c|c|c|c|}
\hline & \multicolumn{4}{|c|}{ Mechanisms and instruments } & \multirow{2}{*}{$\begin{array}{c}\text { Main } \\
\text { stakeholders }\end{array}$} \\
\hline & $\begin{array}{l}\text { Technology } \\
\text { Programme }\end{array}$ & $\begin{array}{l}\text { Industrial } \\
\text { Participation }\end{array}$ & $\begin{array}{l}\text { Centre of } \\
\text { Excellence }\end{array}$ & $\begin{array}{l}\text { Immaterial Property } \\
\text { Right }\end{array}$ & \\
\hline A. Capability view & $\begin{array}{c}\text { Intelligence as a } \\
\text { customer, commitment } \\
\text { to strategic } \\
\text { competence areas }\end{array}$ & Security of supply & $\begin{array}{l}\text { Sustainment of } \\
\text { strategic competence } \\
\text { areas }\end{array}$ & $\begin{array}{c}\text { Protection of sensitive } \\
\text { information and } \\
\text { knowledge }\end{array}$ & $\begin{array}{c}\text { Defence } \\
\text { Establishiment (DE) }\end{array}$ \\
\hline B. Competitiveness view & $\begin{array}{c}\text { Strengthening } \\
\text { competencies, national } \\
\text { networking }\end{array}$ & $\begin{array}{l}\text { Business base, } \\
\text { international } \\
\text { networking }\end{array}$ & $\begin{array}{l}\text { Critical mass of } \\
\text { competence }\end{array}$ & $\begin{array}{c}\text { Ability to take } \\
\text { advantage of } \\
\text { developed systems } \\
\text { commercially }\end{array}$ & $\begin{array}{c}\text { Defence } \\
\text { Industry (DI) }\end{array}$ \\
\hline C. Economic view & Investment & Rieturn of inves tment & Decrease of costs & Source for income & $\begin{array}{l}\mathrm{DE}, \mathrm{DI}, \text { public of } \\
\text { rinland }\end{array}$ \\
\hline D. Management view & Risk mitigation & $\begin{array}{l}\text { Maximising direct } \\
\text { industrial participation }\end{array}$ & $\begin{array}{l}\text { Effectiveness of } \\
\text { project management }\end{array}$ & $\begin{array}{l}\text { Maximising use of } \\
\text { innovations funded by } \\
\text { public funds }\end{array}$ & $\mathrm{DE}, \mathrm{Dl}$ \\
\hline
\end{tabular}

Table 2. Interdependencies and the related reasons and interests between the collaboration views, mechanisms and the main stakeholders

The influence diagram (Figure 2) and the matrix (Table2) lay foundation for the holistic collaboration model of this paper, which attempts to take into consideration all required aims, views and mechanisms to form a unified whole. 


\section{The holistic model of Systems Approach for the collaboration}

On the basis of the Chapters 4 and 5, where existing collaboration mechanisms were described and their interdependencies presented, in this Chapter a holistic model by systems approach is presented. The model represents to-be state of the collaboration.

The holistic collaborative model and arrangement between the defence establishment and the national industry should naturally take capability, competitiveness, economic and management views into consideration in a balanced fashion. In other words, this arrangement should provide a win - win situation not just for the defence establishment and the industry but also for the public. Moreover, the model should be capable of incorporating all laid guidance, e.g. the establishment of DCoEs and the strategic competence areas into its architecture. Consequently, at the beginning of the Chapter requirements and constraints are introduced, which need to be fulfilled in order to make the model reality in future. The requirements of this holistic conceptual model are described in accordance with the collaboration views to stress the functional aspects, i.e. outcomes of the collaboration. Then, the views are complied together as a systems diagram and a data model to visualise the comprehensive model where all collaboration elements; views, mechanisms and stakeholders are included.

\subsection{Management view}

From the management perspective, the DCoEs would provide the necessary long-term organisational and management functions to link technology programmes and industrial participation in the desired strategic competence areas. They could also be used to manage collaboration between national and international partners. DCoEs could take care of the planning, decision making, directing, organising, co-ordinating, controlling, motivating, evaluating and communicating functions between suppliers and customers to provide purposeoriented ways to transform inputs, such as materials, guidance, funds and human resources into outputs, such as processes, services and products ${ }^{(33)}$.

DCoEs should be established during technology programmes (mentioned in Chapter 4.1) to create and increase the knowledge base and gain synergies within the national industry. Equally, DCoEs would enable the national industry and academia to network with clear objectives and to create required mass of 
competence. DCoEs would in turn help manage the industrial efforts comprehensively and provide a single-source gateway for communication between the industry and the defence establishment or foreign suppliers during technology programmes and IP work. This would increase the effectiveness from the project management perspective.

Established DCoEs should create their own business strategies to further develop and transform the knowledge gained through technology programmes into the required services and products. This enables DCoEs to supply these services and products in a competitive manner in IP situations and to market them effectively. It is also very crucial that the terms of reference for DCoEs are rigorously set to meet the desired management aims of the various collaboration mechanisms.

The establishment, implementation, internal structure or financing of the DCoEs are not discussed in detail in this paper, for they are issues of further research. Nevertheless, it should also be mentioned that there are several ongoing $\mathrm{CoE}$ programmes in the Finnish civil sector. These programmes could provide excellent models for the development of DCoEs. They might also prove to be important interfaces in national networking.

The national strategy for the Strategic Centres for Science, Technology and Innovation (CSTI) ${ }^{(34)}$ compares various management models for CoEs, discusses the roles of stakeholders and recommends a most suitable model to be used. The National Centre of Expertise Programme is a national programme that aims to merge local, regional and national resources to use expertise ${ }^{(35)}$. This programme could enable local and regional cooperation between the civilian CoEs and DCoEs. Furthermore, Tekes, the Finnish Funding Agency for Technology and Innovation, which is the main public funding organisation for research, development and innovation in Finland could become a cooperative organisation with DCoEs and their related programmes. Tekes programmes concentrate on areas considered to be important for Finnish business and society. These programmes provide opportunities for companies to carry out research and development projects, facilitate exchange of information, and to enable networking between companies and research establishments. ${ }^{(36)}$

\subsection{Capability view}

From the military capability perspective, it is essential that necessary security of supply is established and maintained onshore. Realisation of this aim 
requires that both technology programmes and IP activities should primarily focus on the same strategic competence areas. Those areas should be military capability driven but should also take into consideration the existing industrial base and its aspirations. The competence areas should be defined as large competence portfolios, e.g. situational awareness, to enable the creation of industrial mass and to increase flexibility. The competence areas should be long-lasting allowing a knowledge and competence build-up. The competencies areas should further include areas that allow domestic industrial involvement during the operations phase of the procured military systems. This approach would increase the security of supply and assure that through-life costs are returned to Finland. The common competence areas in technology programmes and in IP pave way for the required competitiveness of the national defence industry during the procurement projects as an IP partner but perhaps also as a potential main supplier.

\subsection{Competitiveness view}

From the competitiveness perspective, the industry should link mutually defined technology programmes into its business strategies to enable further development of the technology demonstrators into products by its own funding. Likewise, the establishment of required competitiveness for IP related work requires this effort.

The international cooperation between national and foreign DCoEs would be an opportunity for the industry to become more internationalised. However, as national aims and practices may differ from one country to another considerably, the cooperation in technology programmes between foreign DCoEs might prove challenging. In addition, during these technology programmes nationally sensitive information might be handled. Likewise, the funding for these technology programmes comes mainly from the public sector, which, in general, tries to invest in national assets. Due to these challenges, international cooperation should be saved for the IP phase.

Furthermore, IP mechanisms allow direct technology transfer with less effort than collaboration in technology programmes. Correspondingly, the Finnish DCoEs should primarily seek partners from Finland during the technology programme phase and international cooperation should be, in general, established at a later stage and channelled through IP activities. 


\subsection{Economic view}

Implementation of the measures, mentioned in the previous sub-chapters, would enhance the competitiveness of the national defence industry. The industry would be better-equipped than before to supply a bigger portion of the offered IP work and more competitive to sell products and services. Increased IP work would hopefully also lead to an increase in international business connections, which in turn would contribute to the creation of new business opportunities for the industry. Furthermore, the public costs of the defence establishment and the defence industry collaboration would in this case be returned back to the public as jobs and taxes.

\subsection{Stakeholder responsibilities}

With regard to stakeholders, the main role of the defence establishment would be to show and execute a long term commitment in its collaboration with the defence industry. This commitment should be carried out first by building and communicating the holistic model of collaboration as proposed in this paper to the defence industry. However, the industry should be involved in defining and setting up the scene and mechanisms.

During technology programmes, commitment would require direct funding and indirect support by the IPR handover mechanisms. Equally, the defence establishment should lay a firm foundation for the DCoEs. Their aims, roles and tasks during the technology programmes and IP should clearly be defined to help the industry to establish and run the DCoEs with a proper set-up. It should also be noted that the defence establishment should not have a separate funding for the DCoEs. Rather, their support should come from the technology programmes and IP arrangements they are participating in.

Moreover, the defence establishment should clearly state in its procurement guidance how to utilise IP mechanisms to bring add-on value. IP should primarily be targeted for the procurement projects in concern and secondarily, for the development of other military capabilities. Likewise, the DCoEs' role as gateways to engage national industry with IP should be stressed. Nevertheless, DCoEs should not be seen as the only potential national suppliers of the required IP work. Indeed, other firms should also be encouraged to compete for the role of the national supplier to further increase competitiveness. However, in reality DCoEs should be able to meet the IP requirements better than any individual firm in most cases. This is due to their managerial competence and extent of competence, i.e. critical mass, to form sufficient IP work. Moreover, due to their 
systematic competence and competitiveness build-up they should more capable of delivering products most cost-effectively.

The defence industry should commit to this collaboration as well. Technology programmes should, at least partly, be based on mutual funding between the military and the industry. The establishment and running the DCoEs belong to the industry. This is why the defence industry should seek and apply the most appropriate business models to run these organisations during their technology programmes and IP cases as well as in situations where DCoEs bid for procurement projects as any supplier.

\subsection{The holistic collaboration model}

Figure 3 illustrates the conceptual collaboration model between the defence establishment and national industry. It compiles the main stakeholders and all collaboration mechanisms into one framework. The systems diagram shows also the data flows between the elements to illustrate roles, tasks and deliverables of the defence establishment and industry in individual mechanisms.

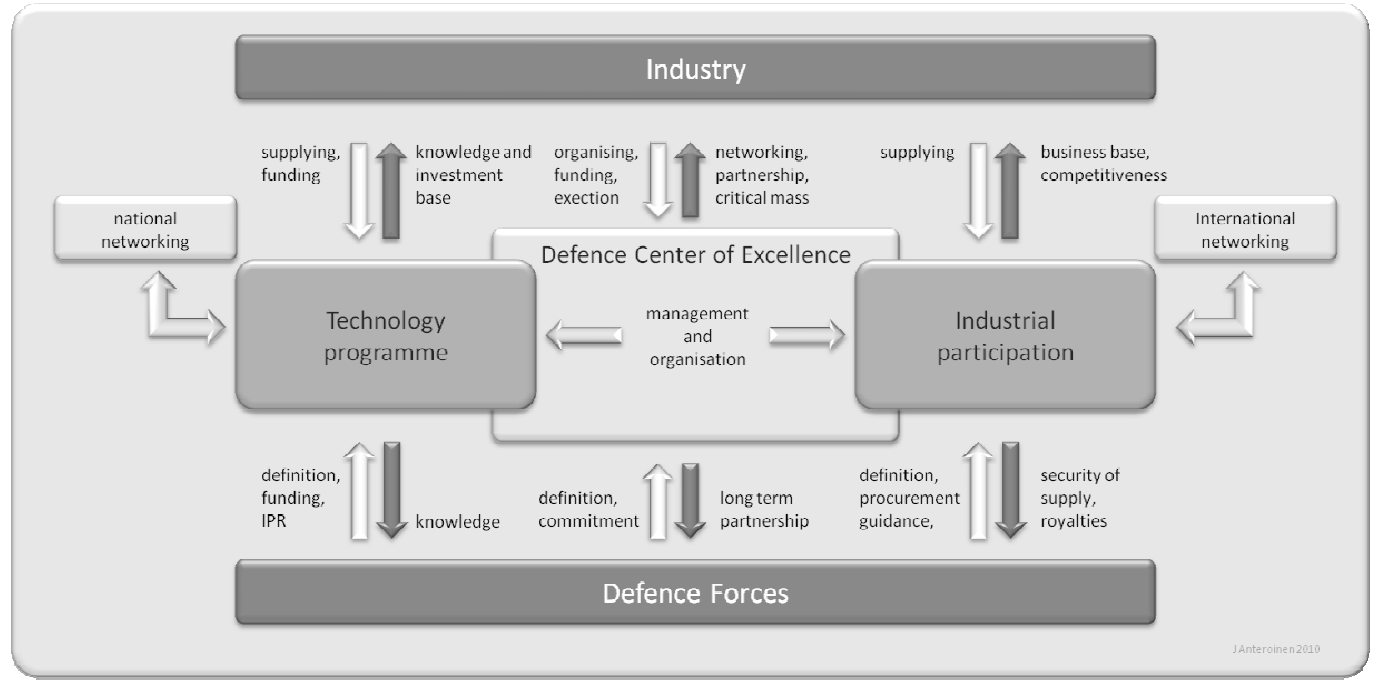

Figure 3. The conceptual model of the enhanced collaboration between the defence forces and national industry

It has been created by taking into account the collaboration requirements that are described in the previous chapters as follows: 
- The role of the DCoE as a hub between the technology programmes and industrial participation including its tasks was described Chapter 6.1.

- The role and tasks of the defence establishment was presented in Chapters 6.2 and 6.5

- The industry's responsibilities and role were delineated in Chapters 6.3 and 6.5 .

- $\quad$ The networking schemes were explained in Chapter 6.1.

The information model of the proposed collaboration model is shown in Figure 4. It clarifies in detail how various collaborative elements interact and form a whole, although in reality, they are implemented under separate programmes, schemes, and mechanism and at different times. Moreover, the information model presents also explicitly the collaboration views: capability, competitiveness, economic and management and show how they link with other element of the collaboration. The holistic approach enables us to see each element in this collaboration as part of a larger scheme and helps to define interfaces with other components as well as supports the achievement of overall objectives. The data sources of Figure 4 are same as in Figure 3.

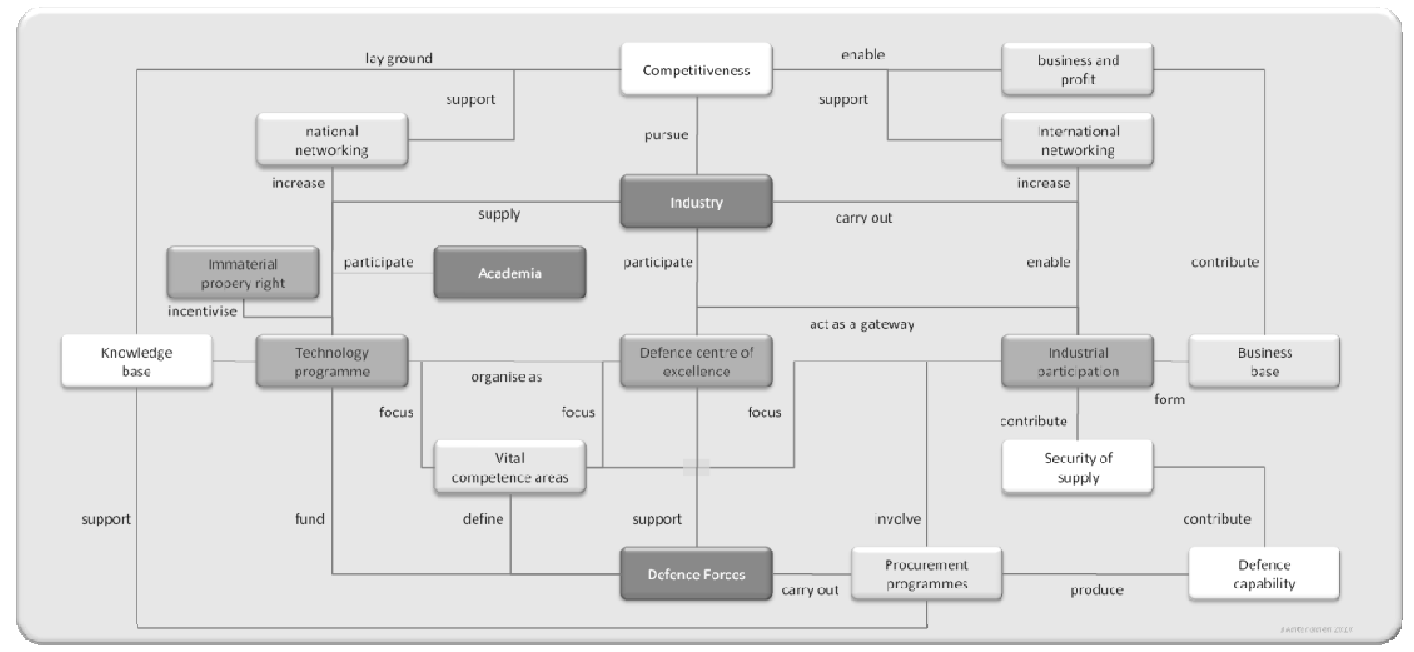

Figure 4. The information model of the enhanced collaboration between the defence establishment and the national defence industry 


\section{Discussion}

A rationale and need exists for national collaboration between the defence establishment and local industry including the R\&D, offset (IP) and organisational elements. The collaboration mechanisms should be managed comprehensively to support the capability, competitiveness, management and economic views.

National competitiveness is a foundation for international collaboration in Europe, which will hopefully eventually lead to a common European Defence Technological and Industrial Base. Consequently, national collaboration mechanisms should not be used for increasing protectionism. Rather, they should be used as means to enhance local competitiveness in order to facilitate internationalisation of the defence industry. Simultaneously, the security of supply would be increased.

If the proposed holistic collaboration model is applied, the national industry will become more capable to deliver direct industrial participation (IP) work. This in turn should lead into an improved security of supply. In this model, competitiveness of the national industry is enhanced directly with technology programmes and IP work, which both focus on the same strategic competence areas. Financially, this model helps to justify both for the military personnel and the Finnish public the financial investment in technology programmes and IP activities. This is due to the fact that the model enables the return of the invested funds back to Finland to contribute to the development of her military capabilities and national industry. From the management perspective, a single source interface, such as DCoE, instead of multiple business counterparts makes the management of technology programmes and IP activities more effective.

This comprehensive understanding and view is vital both for the defence establishment and industry. For the industry especially, understanding that the knowledge gained through technology programmes can be exploited in real business and turned into profit gives them incentive to invest in this collaboration.

However, this cooperation does not bring add-on value automatically. There are pre-requisites and constraints for success. Real success in this national collaboration between the defence establishment and the industry requires longterm commitments. In addition, participants should have a clear understanding of how the potential outcomes of these programmes compare with their own aims. Still, perhaps the most important aspect of making all this work is the participants' willingness and ability to contribute to this system as a whole. 


\section{References}

1. Hartley K. Collaboration and European defence industrial policy. Defence \& Peace Economics. [Article]. 2008;19(4):303-15.

2. Struys W. The future of the defence firm in small and medium countries. Defence \& Peace Economics. [Article]. 2004;15(6):551-64.

3. Braddon D. The matrix reloaded - what future for the defence firm? Defence $\&$ Peace Economics. [Article]. 2004;15(6):499-507.

4. EDA. A Strategy for the European Defence Technological and Industrial Base. Brussels: European Defence Agency; 2007. p. 7.

5. Wylie R, Markowski S, Hall P. Big science, small country and the challenges of defence system development: an Australian case study. Defence \& Peace Economics. [Article]. 2006;17(3):257-72.

6. Ministry of Defence - Finland [Puolustusministeriö]. Defence industrial strategy [Puolustus- ja turvallisuusteollisuusstrategia]. 2007.

7. Defence Staff - Finland [Pääesikunta]. End of year accounts 2006 of the Finnish Defence Forces [Puolustusvoimat - Tiliviraston tilinpäätös 2006]. Helsinki, Finland: Puolustusvoimat; 2007.

8. Churchman CW. The systems approach. Dell Publishing, 1968; 1968.

9. Sage AP, Armstrong JE. Introduction to systems engineering. New York: Wiley; 2000.

10. Kramer NJTA, Smit Jd. Systems thinking : concepts and notions. Leiden: Martinus Nijhoff Social Sciences Division; 1977.

11. De Greene KB. Systems and psychology. In: Beishon J, Peters G, editors. Systems Behaviour. London, Great Britain: The Open University Press; 1972. p. 92 -127.

12. Jenkins GM. The systems approach. In: Beishon J, Peters G, editors. Systems Behaviour. London, Great Britain: The Open University Press; 1972. p. 56 - 82.

13. Hitchins DK. Putting systems to work. Chichester: Wiley; 1992.

14. Skyttner L. General systems theory : ideas \& applications. Singapore ; River Edge, N.J.: World Scientific; 2001.

15. Blanchard BS, Fabrycky WJ. Systems engineering and analysis. 4th ed. ed. Upper Saddle River, N.J. ; London: Prentice Hall; 2005.

16. Checkland P. Researching systems methodology: Some future prospects. In: Flood RL, Jackson MC, Keys P, editors. Systems Prospects - The Next ten years of systems research. New York: Plenum Press; 1989. p. 9-15.

17. The BusinessDicitionary.com. "competitiveness". 2010. [cited 2010, 22.3.2010]; Available from: http://www.businessdictionary.com/definition/competitiveness.html

18. The Oxford Essential Dictionary of the US Military. "military capability". 2001. [cited 2010, 22.3.2010]; Available from: http://www.encyclopedia.com/doc/1O63-militarycapability.html.

19. James AD. The transatlantic defence R\&D gap: causes, consequences and controversies. Defence \& Peace Economics. [Article]. 2006;17(3):223-38.

20. Bellais R, Guichard R. Defense innovation, technology transfers and public policy. Defence \& Peace Economics. [Article]. 2006;17(3):273-86.

21. Kelly T, Rishi M, Hartley K, Warner JT. An empirical study of the spin-off effects of military spending. Defence \& Peace Economics. [Article]. 2003;14(1):7.

22. McGuire MC. Uncertainty, risk aversion, and optimal defense against interruptions in supply. Defence \& Peace Economics. [Article]. 2006;17(4):287-309.

23. Ford D, Saren M. Technology strategy for business. London: International Thomson Business Press; 1996. 
24. Hartley K. Defence R\&D: data issues. Defence \& Peace Economics. [Article]. 2006;17(3):169-75.

25. EDA. The Code of Conduct on Offsets. Brussels 2008.

26. Anteroinen J. A Critical Analysis of the Defence Technology Strategy in Finland from the Systems Approach Perspective. Shrivenham, United Kingdom: Cranfield University. 2006.

27. Ministry of Defence - Finland [Puolustusministeriö]. Materiel Policy Strategy of the Ministry of Defence [Puolustusministeriön Materiaalipoliittinen Strategia]. Helsinki, Finland: Puolustusministeriö; 2007. p. 30.

28. Ministry of Employment and the Economy of Finland. The Official Internet site of the Ministry of Employment and the Economy of Finland. 2009 [cited 2009, 17.11.2009]; Available from: http://www.tem.fi/index.phtml?1=en\&s=2221

29. Gopalaswamy S. Offset Investment Inflow Priorities for Ordnance Factories. Journal of Defence Studies by Institute for Defence Studies and Analyses. 2009;3(1).

30. Prime Minister's Office - Finland. Finnish Security and Defence Policy 2004. Prime Minister's Office; 2004. p. 172.

31. Defence Staff - Finland [Pääesikunta]. Competences and Competitiveness of the National Defence Industry in European networkd environment 2025 [Kotimaisen teollisuuden osaaminen ja kilpailukyky vuonna 2025 verkottuneessa eurooppalaisessa toimintaympäristössä]. [Report]. In press 2005.

32. Defence Staff - Finland [Pääesikunta]. Intellectual proprerty rights in the technical research and development [Teknisen tutkimus- ja kehittämistoiminnan imateriaalioikeuksista puolustusvoimissa]. In: (J10) MD, editor.: Finnish Defence Forces; 2005.

33. Granstrand $\mathrm{O}$. Technology, management and markets : an investigation of $\mathrm{R} \& \mathrm{D}$ and innovation in inndustrial organizations. London: F Pinter; 1982.

34. The Science and Technology Policy Council of Finland [Tiede- ja Teknologianeuvosto]. Strategy for the development of the Strategic Centres for Science, Technology and Innovation [Strategisen huippuosaamisen keskittymät - strategia]. Helsinki, Finland: The Science and Technology Policy Council of Finland; 2006. p. 48.

35. Centre of Expertise Programme [Osaamiskeskusohjelma]. The Ofiicial Internet site of the Centre of Expertise Programme [Osaamiskeskusohjelma]. 2007 [cited 2009 8.12.2009]; Available from: http://www.oske.net/en/.

36. Tekes - The Finnish Funding Agency for Technology and Innovation. The official internet site of Tekes. Helsinki, Finland: Tekes; 2007 [cited 2009 8.12.2009]; Available from: http://www.tekes.fi. 